\title{
Effect of Blended Fertilizer Formulas on Teff [Eragrostis tef (Zucc.) Trotter] Yield and Soil Chemical Properties on Acidic Soils Under Limed Conditions at Nedjo, Western Ethiopia
}

\author{
Fekadu Mosissa Geremew Taye \\ Ethiopian Institute Agricultural Research (EIAR) Holeta Agricultural Research Center, PoBox-2003, Addis \\ Ababa
}

\begin{abstract}
Teff [Eragrostis tef (Zuccagni) Trotter], is a cereal crop species unique to Ethiopia, where it is an important staple food crop. It is grown for its tiny nutritious seeds. Even though, it is highly adapted to different agroecological conditions, its yield is constrained by different factors including declining soil fertility and improper utilization of fertilizer. An experiment was conducted to validate blended fertilizer formulas and levels under limed and unlimed conditions on teff grain yield and soil chemical properties of Nedjo area, west Wollega, Ethiopia. The treatments were comprised of eleven different types and levels of fertilizers[Blanket NP recommended(RNP), NPSB, NPSZnB, modified NPSZnB, NPKSZnB, RNP+lime, NPSB+lime, NPSZnB+lime, modified NPSZnB+lime, NPKSZnB+lime (after Agricultural Transformation Agency, ATA) and Control(0)]. The most yielder teff variety Kuncho was used as a test crop and planted in $20 \mathrm{~cm}$ row spacing. The experiment was laid out in RCB design with three replications. The result revealed that application of balanced fertilization (macro and micro nutrients) + lime (treatment no, 11) has significantly increased grain yield compared with other treatments. Treatment no 7 (Recommended NP + lime) gave better grain yield. Treatment number 11 and 7 increased the grain yield $1322 \%$ and $978 \%$ respectively compared to the control. Blended fertilizers which have lime in addition showed a gradual $\mathrm{pH}$ increase and a sharp decline of exchangeable acidity. The available phosphorous of the soil was improved from 5.508 to $6.748 \mathrm{ppm}$ with the application of recommended NP and lime (treatment 7).Calcium content of the soil has showed an improvement with the application of lime. It is concluded that balanced fertilization with lime has significant and positive response to teff yield and improves some acid soil parameters in the study area. Hence, it is recommended to apply macro and micro nutrients (balanced fertilization) with lime in order to attain optimum grain yield of teff around Nedjo area western wollega.
\end{abstract}

Keywords: Acidic soil, blended fertilizer, Eragrostis tef (Zucc.) Trotter, lime

DOI: $10.7176 / \mathrm{JNSR} / 9-1-01$

\section{Introduction}

Teff [Eragrostis tef (Zuccagni) Trotter], belongs to the grass family poaceae, is a cereal crop species unique to Ethiopia, where it is an important staple crop. It is grown for its tiny nutritious seeds. It is considered a low-risk crop from the perspectives that it can be cultivated in a broad range of ecological surroundings and under tough environmental conditions where most other cereals fail. It is widely grown from sea level up to $2800 \mathrm{~m}$ above sea level (a.s.1.) under various rainfall, temperature, and soil conditions (Seyfu 1997). The most common utilization of teff in Ethiopia is the fermented flat bread called injera (Zhu F, 2018). Crymes (2015) described this traditional flat bread as a soft, thin pancake with a sour taste. Other utilizations of teff include local alcoholic beverages called tela and katikala, and porridge (Abraham R., 2015). The crops' potential is also explored as a thickener for soup, stew, gravy and baby food (Agri Future Australia, 2017).

Recently, teff has been recognized and is highly appreciated as a 'superfood' (Baye, 2015; Heuzé et al., 2016; Shumoy and Raes, 2017). It is relatively rich in protein, ranging from $8.4-19.4 \%$ of dry matter, depending on the cultivar, location, and year (CGIAR, 2009), but is gluten-free, and therefore considered an excellent solution for the increasing gluten-sensitive population worldwide (Baye, 2015).

The Central Statistical Authority (CSA, 2014, CSA, 2010) stated that despite its versatility in adapting to extreme environmental conditions, the productivity of teff in the country is very low ranging 1.28 up to $1.5 \mathrm{tha}^{-1}$ under traditional practices.

The primary biophysical limitations, among others, that decrease agricultural production in Ethiopia are poor soil health, low soil fertility, and crop nutrient imbalances (Gete et al., 2010, Tarekegn, 2010). Core constraints in Ethiopian soils include depletion of soil organic matter due to widespread use of biomass as fuel, depletion of macro- and micronutrients, removal of top soil by erosion, and change of soil physical properties (Gete et al., 2010).

In Ethiopia commercial fertilizer mainly in the form of Urea and DAP was introduced in the 60s by higher learning institutions through limited laboratory and research activities (Murphy, 1968). This was followed in the early $70 \mathrm{~s}$ by nationwide on-farm demonstrations trials and as a result of these works a blanket rate of $100 \mathrm{~kg} \mathrm{ha}^{-}$ 
${ }^{1}$ UREA (46-0-0 kg ha $\left.{ }^{-1} \mathrm{~N}-\mathrm{P}_{2} \mathrm{O}_{5}-\mathrm{K}_{2} \mathrm{O}\right)$ or $50 \mathrm{~kg} \mathrm{ha}^{-1}\left(23-0-0 \mathrm{~kg} \mathrm{ha}^{-1} \mathrm{~N}-\mathrm{P}_{2} \mathrm{O}_{5}-\mathrm{K}_{2} \mathrm{O}\right)+100 \mathrm{~kg}$ DAP ha ${ }^{-1}(18-46-0$ $\mathrm{N}-\mathrm{P}_{2} \mathrm{O}_{5}-\mathrm{K}_{2} \mathrm{O}$ ) were recommended irrespective of crop and soil types (Haile and Mamo, 2013; NFIU,1992).

For the past several decades, Ethiopia has imported and used two fertilizers only; this is against the fact that the country's soils have undergone tremendous nutrient depletion and reduced productivity. Due to this longterm unbalanced fertilization practice, deficiency of other nutrients, mainly potassium $(\mathrm{K})$, sulfur $(\mathrm{S})$, zinc $(\mathrm{Zn})$ and boron (B) started to become apparent (EthioSIS, 2014; Haile and Mamo, 2013; Astatke et al., 2004).

In Ethiopia, there is a general perception that soils are rich in $\mathrm{K}$ and it was excluded from fertilizer recommendation program, though the information available on soil $\mathrm{K}$ dynamic is very scanty to make informed decision. Recent research work of Wassie and Shiferaw (2011) in southern Ethiopia provides a striking example of how fertilizer use efficiency of potato can be raised when NP fertilizers are combined with K on a locationspecific basis. In this study supplementation of K increased potato tuber yields by $197 \%$ over the standard N-P recommendation alone. Similarly experiments conducted at Atsbi-wenberta Tigray, Northern Ethiopia, revealed that application of $\mathrm{K}$ fertilizer was necessary to increase potato tuber yield (Niguse et al., 2016). Study done by Geremew et al 2015, also revealed that remarkable potato tuber yield increase was obtained when N-P fertilizer supplemented with $\mathrm{K}$ fertilizer sources at Cheah and Welmera districts on acid soils.

Nutrient mining due to sub optimal fertilizer use coupled with agronomically unbalanced fertilizer uses have favored the emergence of multi nutrient deficiency in Ethiopian soils (Asgelil et al., 2007; Abyie et al., 2003;) which in part explain fertilizer factor productivity decline and stagnant crop productivity conditions encountered despite continued use of the blanket recommendation.

Experience in Malawi provides a striking example of how $\mathrm{N}$ fertilizer efficiency for maize can be raised by providing appropriate micronutrients on a location-specific basis. Supplementation by S, Zn, B, and K increased maize yields by $40 \%$ over the standard N-P recommendation alone (John et al., 2000). In Ethiopia, initial results of demonstration of blended fertilizers that include N, P, K, S, Zn, B conducted across 25,000 smallholder farms in different parts of the country indicate sharp increase in cereals yield (ATA unpublished).

Since the blanket fertilizer application of $100 \mathrm{Kg}$ urea and $100 \mathrm{Kg}$ DAP fails to address the current fertility status of the soil and specific crop needs, the country has started using fertilizers which can supply the deficient nutrients in the form of blended or compound fertilizers: NPS, NPSB, NPSZn and NPSZnB; and also an issue of balanced fertilization and liming was immerged for improving acid soil productivity. Therefore, this experiment was conducted at Nedjo, which is a hot spot acid prone area of the country to validate blended fertilizer formulae and investigate the importance of lime on nutrient release of acid soil.

\section{Materials and Methods}

Study site

The experiment was conducted at Nedjo testing site, which is located in western Wollega. The research was conducted for three years $(2015$ - 2017). The experimental site is situated at an altitude of 1933m.a.s.l, longitudes $09^{0} 33^{\prime} 07.2^{\prime \prime} \mathrm{N}$ and latitude $035^{\circ} 25^{\prime} 49.8$ " E. Its annual rainfalls are around $1300-1500 \mathrm{~mm}$ and mean annual temperature fall between $18^{\circ} \mathrm{c}$ and $28^{\circ} \mathrm{c}$. The soil at the test site is nitosol having about $60 \%$ clay proportion and the farming system in the area is crop and livestock mixed agriculture.

\section{Soil sampling and analysis}

The soil samples of the experimental site were collected before planting and after harvesting from $0-0.15 \mathrm{~m}$ plough depth. Before planting a representative soil samples were taken from an experimental field randomly and composited to one sample for soil characterization. Before the commencement of the experiment soil samples were analyzed for exchangeable acidity for the determination of lime rate to be applied. After harvest soil samples were collected on treatment bases in three replications and composited along treatments.

The collected soil samples were analyzed for the selected chemical properties (pH, Pav., TN, exchangeable acidity (EA), exchangeable bases ( $\mathrm{Na}, \mathrm{K}, \mathrm{Ca}, \mathrm{Mg}$ ), micronutrients ( $\mathrm{Mn}, \mathrm{Cu}, \mathrm{Fe}, \mathrm{Zn}$ ). Soil samples were analyzed for texture with a hydrometer (Bouyoucos, 1954). The $\mathrm{pH}$ of the soil is determined with the potentiometer method (1:2.5 soil: water as described by Chopra and Kanwar (1976). Available phosphorus was measured using Bray - II, procedure (Bray and Kurtz, 1945). Total nitrogen was measured using Kjeldhal method (Rainst et al., 1999). Titration method with 1N KCL leaching was used to measure exchangeable acidity (van Reeuwijk, 2002). Exchangeable $\mathrm{Ca}, \mathrm{Mg}, \mathrm{K}$ and $\mathrm{Na}$ in the extract were measured by AAS (Okalebo et al., 2002).

\section{Experimental Design and Procedure}

The experiment was laid out in randomised complete block design (RCBD) with three replications and comprised 11 treatments. The plot area was $3.0 * 4.0$ which is $12 \mathrm{~m}^{2}$.

The amount of lime to be applied was calculated on the basis of the exchangeable acidity, bulk density and $15 \mathrm{~cm}$ depth of the soil. One mole of exchangeable acidity would be neutralized by an equivalent mole of $\mathrm{CaCO}_{3}$ (adopted from Kamprath, 1984). 


$$
L R, \mathrm{CaCO}_{3}(\mathrm{~kg} / \mathrm{ha})=\frac{\mathrm{cmolEA} / \mathrm{kg} \text { of soil } * 0.15 \mathrm{~m}^{*} 10^{4} \mathrm{~m}^{2} * \text { B.D. }\left(\mathrm{Mg} / \mathrm{m}^{3}\right) * 1000}{2000}
$$

Accordingly, the amount of lime for this particular activity was uniformly applied for all plots at 1.5 times of the exchangeable acidity and incorporated in to the soil a month before planting.

Growth parameters such as plant height, panicle length, biomass and grain yield was recorded and evaluated. All data recorded during the course of the experiment was subjected to analysis of variance using SAS software 9.0 (SAS, 2004) and mean separation was computed using Least Significance Difference (LSD) at $5 \%$ probability level (Steel RG and Torrie JH,1986).

The treatment arrangements and application modes was done according to specific blended fertilizer formulation. Treatment setup:

1. Control

2. Recommended NP $\left(140 \mathrm{~kg} \mathrm{ha}^{-1}\right.$ Urea $+150 \mathrm{~kg} \mathrm{ha}^{-1}\left(\mathrm{~N}=91, \mathrm{P}_{2} \mathrm{O}_{5}=69, \mathrm{~K}_{2} \mathrm{O}=0, \mathrm{~S}=0, \mathrm{Zn}=0, \mathrm{~B}=0\right)[\mathrm{RNP}]$

3. Formula 2: $150 \mathrm{~kg} \mathrm{ha}^{-1}+140 \mathrm{~kg} \mathrm{ha}^{-1}$ urea top dressed $\left(\mathrm{N}=91, \mathrm{P}_{2} \mathrm{O}_{5}=54, \mathrm{~K}_{2} \mathrm{O}=0, \mathrm{~S}=10.1, \mathrm{Zn}=0\right.$, $\mathrm{B}=1.06) \quad[\mathrm{NPSB}]$

4. Formula 4: $150 \mathrm{~kg} \mathrm{ha}^{-1}+150 \mathrm{~kg} \mathrm{ha}^{-1}$ urea top dressed $\left(\mathrm{N}=94, \mathrm{P}_{2} \mathrm{O}_{5}=51 \mathrm{~K}_{2} \mathrm{O}=0 \mathrm{~S}=11 \mathrm{Zn}=3.34 \mathrm{~B}=1.01\right)$ [NPSZnB]

5. Formulae 4 modified: $200 \mathrm{~kg} \mathrm{ha}^{-1}+125 \mathrm{~kg} \mathrm{ha}^{-1}$ urea top dressed $\left(\mathrm{N}=93, \mathrm{P}_{2} \mathrm{O}_{5}=70 \mathrm{~K}_{2} \mathrm{O}=0 \mathrm{~S}=15.2\right.$, $\mathrm{Zn}=4.4, \mathrm{~B}=0.5) \quad[$ Modified NPSZnB]

6. Formula5 modified: $200 \mathrm{~kg} \mathrm{ha}^{-1}+145 \mathrm{~kg} \mathrm{ha}^{-1}$ urea top dressed $\left(\mathrm{N}=93, \mathrm{P}_{2} \mathrm{O}_{5}=52, \mathrm{~K}_{2} \mathrm{O}=30, \mathrm{~S}=11.2\right.$, $\mathrm{Zn}=3.44, \mathrm{~B}=0.5) \quad[\mathrm{NPKSZnB}]$

7. Recommended NP $\left(140 \mathrm{~kg} \mathrm{ha}^{-1}\right.$ Urea $+150 \mathrm{~kg} \mathrm{ha}^{-1}\left(\mathrm{~N}=91, \mathrm{P}_{2} \mathrm{O}_{5}=69, \mathrm{~K}_{2} \mathrm{O}=0, \mathrm{~S}=0, \mathrm{Zn}=0, \mathrm{~B}=0\right)+$ lime $[\mathrm{RNP}]+$ lime

8. Formula 2: $150 \mathrm{~kg} \mathrm{ha}^{-1}+140 \mathrm{~kg} \mathrm{ha}^{-1}$ urea top dressed $\left(\mathrm{N}=91, \mathrm{P}_{2} \mathrm{O}_{5}=54, \mathrm{~K}_{2} \mathrm{O}=0, \mathrm{~S}=10.1, \mathrm{Zn}=0 \mathrm{~B}=1.06\right)$ + lime) $[\mathrm{NPSB}]+$ lime

9. Formula 4: $150 \mathrm{~kg} \mathrm{ha}^{-1}+150 \mathrm{~kg} \mathrm{ha}^{-1}$ urea top dressed $\left(\mathrm{N}=94, \mathrm{P}_{2} \mathrm{O}_{5}=51, \mathrm{~K}_{2} \mathrm{O}=0 \mathrm{~S}=11 \mathrm{Zn}=3.34 \mathrm{~B}=1.01\right)$ + lime ) $[\mathrm{NPSZnB}]+$ lime

10. Formula 4 modified: $200 \mathrm{~kg} \mathrm{ha}^{-1} \mathrm{~kg} \mathrm{ha}^{-1}+125 \mathrm{~kg} \mathrm{ha}^{-1}$ urea top dressed $\left(\mathrm{N}=93, \mathrm{P}_{2} \mathrm{O}_{5}=70 \mathrm{~K}_{2} \mathrm{O}=0\right.$ $\mathrm{S}=15.2, \mathrm{Zn}=4.4, \mathrm{~B}=0.5)+$ lime $[\mathrm{NPSZnB}]+$ lime

11. Formula5 modified: $200 \mathrm{~kg} \mathrm{ha}^{-1}+145 \mathrm{~kg} \mathrm{ha}^{-1}$ urea top dressed $\left(\mathrm{N}=93, \mathrm{P}_{2} \mathrm{O}_{5}=52, \mathrm{~K}_{2} \mathrm{O}=30, \mathrm{~S}=11.2\right.$, $\mathrm{Zn}=3.44, \mathrm{~B}=0.5)+$ lime $\quad[\mathrm{NPKSZnB}]+$ lime

\section{Result and discussion}

\section{Yield and Yield Component}

In 2015 the analysis of variance indicated that there was significant variation $(\mathrm{P}<0.05)$ among the treatments evaluated to biomass and grain yield. The analysis of variance for agronomic traits especially biomass $(2467.57$ $\left.\mathrm{kg} \mathrm{ha}^{-1}\right)$ and grain yield $\left(619.14 \mathrm{~kg} \mathrm{ha}^{-1}\right)$ of teff showed significant result with treatment no 11 . The second best result of biomass $\left(1985.99 \mathrm{Kg} \mathrm{ha}^{-1}\right)$ and grain yield $\left(496.42 \mathrm{Kg} \mathrm{ha}^{-1}\right)$ was recorded by treatment no 6 (i.e. Formula 5 modified). From these two results it is possible to conclude that how teff grain yields was increased by providing appropriate micronutrients on a location-specific basis. This result is in close agreement with (John et al., 2000) which stated that with the supplementation of S, Zn, B, and K maize yield increased by $40 \%$ over the standard N-P recommendation alone. In our case teff yield was increased by $213 \%$ over the standard N-P recommendation alone. Balanced fertilization and lime (treatment no.11) increased teff grain yield by $125 \%$ over the treatment balanced fertilization without lime (treatment no.6).

The grain yield ranged from $29.78\left(\mathrm{~kg} \mathrm{ha}^{-1}\right)$ to $619.14\left(\mathrm{~kg} \mathrm{ha}^{-1}\right)$ while the mean grain yield recorded was $340.86\left(\mathrm{~kg} \mathrm{ha}^{-1}\right)$. The best plant height performance and panicle length was recorded by treatment no 11 . The highest harvest index was recorded by treatment no 5 (27.66), showing that more grain yield over biological yield (Table 1). 
Table 1. Effect of blended fertilizer on teff with limed \& unlimed condition (2015) - Nedjo

\begin{tabular}{|c|c|c|c|c|c|}
\hline Treatment & PLHT & Pn Ln & $\begin{array}{c}\mathrm{BM} \\
\left(\mathrm{Kg} \mathrm{ha}^{-1}\right)\end{array}$ & $\begin{array}{c}\mathrm{GY} \\
\left(\mathrm{Kg} \mathrm{ha}^{-1}\right)\end{array}$ & HI \\
\hline 1 & 25.60 & 23.33 & 503.45 & 29.78 & 5.68 \\
\hline 2 & 38.20 & 33.07 & 1124.02 & 289.86 & 20.50 \\
\hline 3 & 34.60 & 32.40 & 782.70 & 180.48 & 18.64 \\
\hline 4 & 36.80 & 34.20 & 721.41 & 182.65 & 20.21 \\
\hline 5 & 38.87 & 32.67 & 900.08 & 348.30 & 27.66 \\
\hline 6 & 45.87 & 36.00 & 1985.99 & 496.42 & 19.93 \\
\hline 7 & 37.27 & 33.86 & 1126.58 & 397.89 & 25.87 \\
\hline 8 & 35.93 & 33.13 & 1796.12 & 369.51 & 16.94 \\
\hline 9 & 35.80 & 30.67 & 1564.98 & 398.38 & 20.20 \\
\hline 10 & 36.27 & 32.13 & 1525.85 & 437.01 & 21.89 \\
\hline 11 & 44.93 & 37.45 & 2467.57 & 619.14 & 20.07 \\
\hline Mean & 37.28 & 32.63 & 1318.07 & 340.86 & 19.78 \\
\hline $\mathrm{CV}(\%)$ & 19.95 & 8.32 & 6.85 & 25.05 & 17.99 \\
\hline LSD & 12.67 & 4.63 & 153.88 & 145.46 & 6.06 \\
\hline \multicolumn{6}{|c|}{$\begin{array}{l}\text { PLHT = plant height, PnLn = panicle length, BM= Biomass, GY= grain yield, } \\
\text { HI }=\text { harvest index } \\
1=\mathrm{Control}, 2=\mathrm{RNP}, 3=\mathrm{NPSB}, 4=\mathrm{NPSZnB}, 5=\text { Formula } 4 \text { modified, } 6=\mathrm{NPKSZnB}, 7=\mathrm{RNP}+\mathrm{Lime} \text {, } \\
8=\mathrm{NPSB}+\text { lime, } 9=\mathrm{NPSZnB}+\text { lime, } 10=\text { Formula } 4 \text { modified }+ \text { lime, } 11=\mathrm{NPKSZnB}+\text { lime. } \\
\text { The analysis of variance for the data in } 2016 \text { was indicated on table } 2 \text {. All the studied parameters showed } \\
\text { significance difference at }(\mathrm{p}<0.05) \text { among treatments. Similar to the data in } 2015 \text {, the highest significant result of } \\
\text { biomass }\left(5170.6 \mathrm{~kg} \mathrm{ha}^{-1}\right) \text {, grain yield }\left(1665.4 \mathrm{~kg} \mathrm{ha}^{-1}\right) \text { plant height }(101.53 \mathrm{~cm}) \text { and panicle length }(46.53 \mathrm{~cm}) \text { of } \\
\text { teff was recorded with treatment no } 11 \text {.The second best result of grain yield }\left(1313.2 \mathrm{~kg} \mathrm{ha}^{-1}\right) \text { was obtained by } \\
\text { treatment no } 7 \text { (i.e., recommended NP + lime). } \\
\text { Table } 2 \text {. Effect of blended fertilizer on teff with limed \& unlimed condition }(2016)-\mathrm{Nedjo}\end{array}$} \\
\hline Treatment & $\begin{array}{c}\text { PLHT } \\
\text { (cm) }\end{array}$ & PnLn (cm) & $\begin{array}{c}\text { BM } \\
\left(\mathrm{Kg} \mathrm{ha}^{-1}\right)\end{array}$ & $\begin{array}{c}\mathbf{G Y} \\
\left(\mathrm{Kg} \mathrm{ha}^{-1}\right)\end{array}$ & HI \\
\hline 1 & 60.53 & 32.00 & 396.9 & 115.4 & 22.51 \\
\hline 2 & 91.20 & 43.20 & 2617.5 & 784.8 & 23.32 \\
\hline 3 & 84.67 & 41.73 & 1555.7 & 503.5 & 24.35 \\
\hline 4 & 84.40 & 40.47 & 1826.0 & 607.9 & 24.47 \\
\hline 5 & 87.13 & 42.53 & 1837.2 & 971.7 & 35.22 \\
\hline 6 & 95.27 & 44.73 & 2439.1 & 993.0 & 28.94 \\
\hline 7 & 89.00 & 45.00 & 2809.6 & 1313.2 & 32.49 \\
\hline 8 & 91.07 & 45.26 & 3115.0 & 1128.1 & 28.40 \\
\hline 9 & 85.73 & 43.33 & 2698.5 & 1252.1 & 31.61 \\
\hline 10 & 85.60 & 43.80 & 3073.7 & 1142.9 & 27.21 \\
\hline 11 & 101.53 & 46.53 & 5170.6 & 1665.4 & 24.37 \\
\hline Mean & 86.92 & 42.60 & 2503.6 & 952.55 & 27.53 \\
\hline CV (\%) & 9.11 & 5.27 & 23.61 & 20.65 & 12.34 \\
\hline LSD & 13.49 & 3.82 & 1006.8 & 335.08 & 5.79 \\
\hline
\end{tabular}

PLHT = plant height, $P n L n=$ panicle length, BM= Biomass, $G Y=$ grain yield, $H I=$ harvest index.

$1=$ Control, $2=R N P, 3=N P S B, 4=N P S Z n B, 5=$ Formula 4 modified, $6=N P K S Z n B$,

$7=R N P+$ Lime, $8=N P S B+$ lime, $9=N P S Z n B+$ lime, $10=$ Formula 4 modified + lime,

$11=N P K S Z n B+$ lime.

Similar to 2015 and 2016 in 2017 both biomass yield $\left(6102.8 \mathrm{~kg} \mathrm{ha}^{-1}\right)$ and grain $\left(1131.1 \mathrm{~kg} \mathrm{ha}^{-1}\right)$ yield of teff showed significance with treatment no 11 . The second best result of grain yield $\left(900.9 \mathrm{~kg} \mathrm{ha}^{-1}\right)$ was obtained with treatment no $8\left[150 \mathrm{~kg} \mathrm{ha}^{-1}+140 \mathrm{~kg} \mathrm{ha}^{-1}\right.$ urea top dressed $(\mathrm{N}=91, \mathrm{P} 2 \mathrm{O} 5=54, \mathrm{~K} 2 \mathrm{O}=0, \mathrm{~S}=10.1, \mathrm{Zn}=0$, $\mathrm{B}=1.06]+$ lime (Table 3 ). This result indicated that a comparable teff yield might be obtained by $\mathrm{N} P$ fertilizer with $\mathrm{S}$ and boron in the presence of lime. 
Table 3. Effect of blended fertilizer on teff with limed \& unlimed condition (2017) - Nedjo

\begin{tabular}{cccccc}
\hline Trt & PLHT & Pn Ln & $\begin{array}{c}\text { BM } \\
\left(\mathrm{Kg} \mathrm{ha}^{-1}\right)\end{array}$ & $\begin{array}{c}\text { GY } \\
\left(\mathrm{Kg} \mathrm{ha}^{-1}\right)\end{array}$ & HI \\
\hline 1 & 66.00 & 27.93 & 782.4 & 113.0 & 13.08 \\
2 & 87.00 & 36.40 & 3153.7 & 460.6 & 14.79 \\
3 & 88.73 & 33.67 & 2973.2 & 519.1 & 17.30 \\
4 & 85.73 & 36.00 & 2479.7 & 585.9 & 20.24 \\
5 & 77.27 & 29.80 & 2985.2 & 575.4 & 16.22 \\
6 & 100.53 & 40.53 & 3815.7 & 719.5 & 16.38 \\
7 & 98.33 & 38.80 & 5440.8 & 814.0 & 13.04 \\
8 & 108.33 & 44.40 & 5127.8 & 900.9 & 14.93 \\
9 & 99.87 & 39.87 & 4983.3 & 775.0 & 13.38 \\
10 & 96.40 & 39.40 & 4766.7 & 761.1 & 13.80 \\
11 & 106.80 & 39.73 & 6102.8 & 1131.1 & 15.72 \\
\hline Mean & 92.27 & 36.96 & 3873.7 & 668.7 & 15.35 \\
CV $(\%)$ & 10.44 & 9.34 & 22.3 & 13.1 & 23.95 \\
\hline
\end{tabular}

PLHT = plant height, PnLn = panicle length, BM=Biomass, GY= grain yield,

$H I=$ harvest index

$1=$ Control, $2=R N P, 3=N P S B, 4=N P S Z n B, 5=$ Formula 4 modified, $6=N P K S Z n B$,

$7=R N P+$ Lime, $8=N P S B+$ lime, $9=N P S Z n B+$ lime, $10=$ Formula 4 modified + lime,

$11=N P K S Z n B+$ lime.

Combined analysis of variance of 3 years $(2015$ - 2017) biomass and grain yield result of teff showed significance with that of treatment no 11(i.e. Formula 5 modified + lime). The second best grain yield was obtained by treatment 8 (Formula $2+$ lime). Similar to the first and second year result, combined analysis showed the best plant height performance and panicle length with treatment no 11(Table 4).

In general, balanced fertilization in the presence of a soil conditioner lime gave the best teff grain yield and yield component, while a comparative grain yield was obtained by recommended N P with lime. Both in the first and second year and as well in combined analysis of 3years result, treatment 5 have showed better harvest index (Table 4).

Table 4. Effect of Blended Fertilizer on teff yield combination, Analysis of 3years (2015 - 2017) - Nedjo.

\begin{tabular}{cccccc}
\hline Treatment & PLHT & Pn Ln & $\begin{array}{c}\text { BM } \\
\left(\mathrm{Kg} \mathrm{ha}^{-1}\right)\end{array}$ & $\begin{array}{c}\text { GY } \\
\left(\mathrm{Kg} \mathrm{ha}^{-1}\right)\end{array}$ & HI \\
\hline 1 & 50.71 & 27.76 & 560.9 & 86.1 & 13.76 \\
2 & 72.13 & 37.55 & 2298.4 & 511.7 & 19.54 \\
3 & 69.33 & 35.93 & 1770.5 & 401.0 & 20.09 \\
4 & 68.98 & 36.89 & 1675.7 & 458.8 & 21.64 \\
5 & 67.76 & 35.00 & 1907.5 & 631.8 & 21.75 \\
6 & 80.56 & 40.42 & 2746.9 & 736.3 & 23.80 \\
7 & 74.87 & 39.22 & 3125.6 & 841.7 & 20.09 \\
8 & 78.44 & 40.93 & 3346.3 & 799.5 & 20.96 \\
9 & 73.80 & 37.96 & 3082.3 & 808.5 & 20.05 \\
10 & 72.76 & 38.44 & 3122.1 & 780.4 & 20.89 \\
11 & 84.42 & 41.24 & 4580.3 & 1138.5 & 17.80 \\
Mean & 72.16 & 37.40 & 2565.1 & 654.0 & 3.50 \\
\hline
\end{tabular}

$P L H T=$ plant height, $P n L n=$ panicle length, $B M=$ Biomass, $G Y=$ grain yield,

$H I=$ harvest index

$1=$ Control, $2=R N P, 3=N P S B, 4=N P S Z n B, 5=$ Formula 4 modified, $6=N P K S Z n B$,

$7=R N P+$ Lime, $8=N P S B+$ lime, $9=N P S Z n B+$ lime, $10=$ Formula 4 modified + lime,

$11=N P K S Z n B+$ lime.

Soil physic chemical properties

The result of soil physic chemical properties of the teff experimental field is summarized in table 5 and 6 . Particle size distribution of the soil was $15 \%$ sand, $22 \%$ silt and $63 \%$ clay. The soil $\mathrm{pH}$ was improved from initial 4.54 to 4.83 with the application of $200 \mathrm{~kg} \mathrm{ha}^{-1}+145 \mathrm{~kg} \mathrm{ha}^{-1}(\mathrm{~N}=93, \mathrm{P} 2 \mathrm{O}=52, \mathrm{~K} 2 \mathrm{O}=30, \mathrm{~S}=11.2, \mathrm{Zn}=3.44$, $\mathrm{B}=0.5)$ + lime (treatment no 11). In general, all treatments and those treatments which were limed in particular (treatment no 7 up to 11) showed a gradual $\mathrm{pH}$ increments. But these $\mathrm{pH}$ increments never correspond to the suitable $\mathrm{pH}$ range for most crops which is between 6.5 and 7.5 where $\mathrm{N}$ availability is optimum $(\mathrm{FAO}, 2008)$. 
The soil exchangeable acidity has showed a slight decrease where lime was used as part of the treatment. Exchangeable acidity showed an inverse relationship with the soil $\mathrm{pH}$. Soil total nitrogen never showed a substantial difference before the initiation of the experiment and after commencing the experiment.

The available phosphorous of the soil was improved from 5.508 to $6.748 \mathrm{ppm}$ with the application of recommended NP + lime (treatment no 7). The second best $\mathrm{P}$ improvement $(5.988 \mathrm{ppm})$ was recorded by application of $200 \mathrm{~kg} \mathrm{ha}^{-1}+125 \mathrm{~kg} \mathrm{ha}^{-1}$ urea top dressed $(\mathrm{N}=93, \mathrm{P} 2 \mathrm{O}=70 \mathrm{~K} 2 \mathrm{O}=0 \mathrm{~S}=15.2, \mathrm{Zn}=4.4, \mathrm{~B}=0.5)+$ lime (treatment no 10). This showed that lime played a significant role for $\mathrm{P}$ increment both in the presence and absence of micronutrient. Ligeyo DO \& Gudu SO, (2005)has also described the same phenomenon that lime increases $\mathrm{P}, \mathrm{Mg}, \mathrm{Ca}$ and $\mathrm{Mo}$ availability in acidic soils. Therefore, in $\mathrm{P}$ fixing acid soils, combined lime and $\mathrm{P}$ application is necessary for increased availability of the applied $\mathrm{P}$ for plant uptake.

Calcium content of the soil has showed an improvement from $1.137 \mathrm{cmol} \mathrm{kg}^{-1}$ to $2.629 \mathrm{cmol} \mathrm{kg}^{-1}$ that is from very low to low range as described by (FAO, 2006) with the application of lime, and better calcium content was observed with the synergetic effect of lime and micronutrients. Those treatments having micronutrients but not calcite lime have showed an improvement of magnesium from $0.758 \mathrm{cmol} \mathrm{kg}^{-1}$ to $1.025 \mathrm{cmol} \mathrm{kg}^{-1}$ that is from low to medium as described by (FAO, 2006). Potassium (K) content of the soil never showed an improvement before planting and after commencing the experiment.

Manganese and Iron content of the soil has showed a bit increase with treatments having SZnB and lime. Copper $(\mathrm{Cu})$ content of the soil increases under the application of micronutrients and lime. (Table 6).

Table 5. Soil physical properties

\begin{tabular}{|c|c|c|c|}
\hline Treatment & \multicolumn{3}{|c|}{ Percent soil proportion } \\
\hline & Clay & Silt & Sand \\
\hline 1 & 62.5 & 22.5 & 15 \\
\hline 2 & 60 & 25 & 15 \\
\hline 3 & 55 & 25 & 20 \\
\hline 4 & 60 & 20 & 20 \\
\hline 5 & 65 & 20 & 15 \\
\hline 6 & 70 & 20 & 10 \\
\hline 7 & 67.5 & 20 & 12.5 \\
\hline 8 & 62.5 & 25 & 12.5 \\
\hline 9 & 65 & 20 & 15 \\
\hline 10 & 62.5 & 22.5 & 15 \\
\hline 11 & 62.5 & 25 & 12.5 \\
\hline Mean & 63.0 & 22.3 & 14.7 \\
\hline
\end{tabular}

Table 6. Soil physic chemical properties as affected by blended fertilizer under limed \&unlimed condition at Nedjo, West Wollega

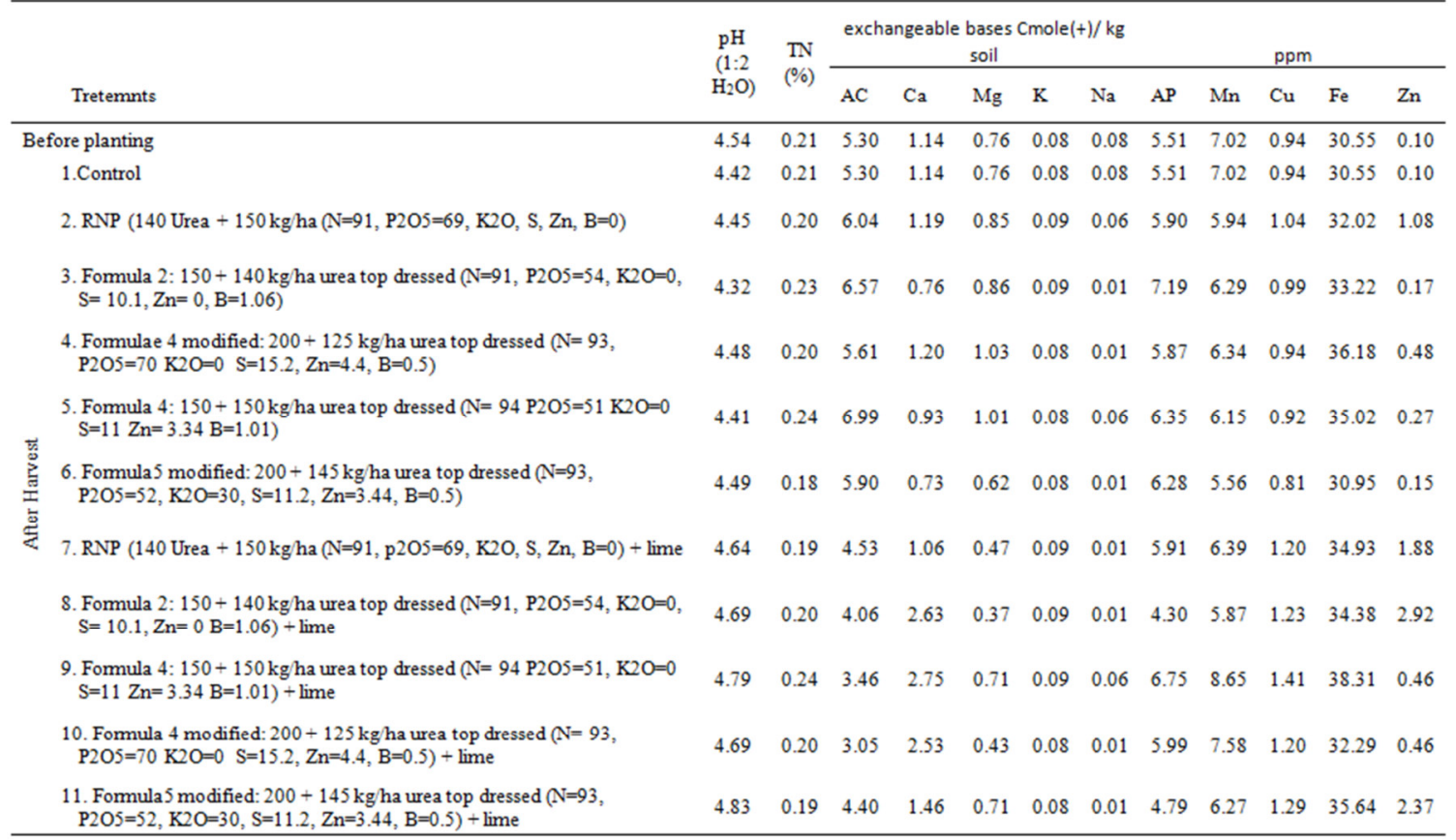

Ac $=$ Exchangeable acidity 


\section{Conclusion and recommendation}

In the study area, use of fertilizer has focused mainly on the use of nitrogen and phosphorous fertilizers in the form of urea and di-ammonium phosphate (DAP) for almost all cultivated crops. Such unbalanced application of plant nutrients with least study might have aggravated the depletion of nutrient elements in soils including the recently identified $\mathrm{K}, \mathrm{S}$ and micronutrients $(\mathrm{Zn}, \mathrm{B})$. The result of this experiment has substantiated the importance of micronutrients ( $\mathrm{Zn}$ and $\mathrm{B}$ ) and $\mathrm{S}$ in combination with macronutrients NPK fertilizers in the presence of a soil conditioner lime. The application of fertilizer containing NPKSZnB with lime (treatment no 11) brought significantly higher yield (1131.1 kg ha-1). Similar result was obtained by Redai Weldegebriel et.al., (2018) sorghum treated by fertilizer contained NPKSZn (macronutrients in combination with micronutrient) gave higher yield.

Therefore, it can be concluded that balanced fertilization with lime increased teff grain yield. The available phosphorous of the soil was improved with the application of recommended NP and lime (treatment no 7). Therefore, NPKSZnB blended fertilizer with lime can be recommended for increased teff productivity particularly in the study area. Further studies are also recommended for fertilizer rate and time of application in teff production.

\section{Acknowledgements}

The authors are grateful to Ethiopian Institute of Agricultural Research and acid soil research team of Holeta Research Centre for provision of facilities, implementation of the experiment and data collection.

\section{References}

Abiye Astatke, Tekalign Mamo, Peden, D. and M. Diedhiou (2003). Participatory On-farm conservation tillage trial in Ethiopian highland vertisols: The impact of potassium application on crop yield. Experimental Agriculture 40:369-379.

Abraham R. (2015). Achieving food security in Ethiopia by promoting productivity of future world food tef: A Review. Adv Plants Agric Res 2015; 2(2): 00045.

AgriFuture Australia (2017). http://www.agrifutures.com.au/farm-diversity /teff/

Asgelil D., Taye B., and Yesuf A. (2009). The Status of Micro Nutrients in Nitisols, Vertisols, Cambisols and Fluvisols in Major Maize, Wheat, Tef and Citrus Growing Areas of Ethiopia.

Astatke, A., T. Mamo, D. Peden, and M. Diedhiou, (2004). Participatory On-Farm Conservation Tillage Trial in Ethiopian Highland Vertisols: The Impact of Potassium Application on Crop Yield. Expl. Agriculture 40:369-379.

Baye, K.,(2015). Teff: Nutrient Composition and Health Benefits. ESSP Working Paper 67. Washington, D.C. and Addis Ababa, Ethiopia: International Food Policy Research Institute (IFPRI) and Ethiopian Development Research Institute (EDRI).

Bouyoucos H.H. (1954): A recalibration of the hydrometer for making mechanical analysis of soils. Agron. J. 43: 343-348.

Bray, R.H. and L.T. Kurtz (1945). Determination of total organic and available phosphorus in soils. Soil Science 59: 39-45.

CGIAR, (2009). SSA Feeds - Sub-Saharan Africa Feed Composition Database. CGIAR System wide Livestock Programme.

Chopra, S.H. andJ.S.Kanwar (1976). Analytical agricultural chemistry. New Delhi: Kalyani publisher Ludhiana.518 p.

Crymes AR. (2015).The international footprint of teff: Resource of an ancient Ethiopia grain, 2015.

CSA, (2014). Agricultural Sample Survey Statistical Bulletin Report on Area and Production of major crops. Addis Ababa, Ethiopia.

CSA, (2010). Agricultural Sample Enumeration Surveys, Addis Ababa, Ethiopia.

EthioSIS (Ethiopian Soil Information System), (2014). Soil Fertility Status and Fertilizer Recommendation Atlas for Tigray Regional State, Ethiopia. July 2014. Ministry of Agriculture and Agricultural Transformation Agency: 92. http:// www.ata.gov.et/download/soil-fertility-status-fertilizerrecommendation-atlas-tigrayregional-state jul2014/.

FAO (Food and Agriculture Organization) (2008). Plant Nutrition for Food Security. A Guide for Integrated Nutrient Management. Rome, Italy.

FAO (Food and Agriculture Organization) (2006). Plant Nutrition for Food Security. A Guide for Integrated Nutrient Management. FAO, Fertilizer and Plant Nutrition Bulletin 16, Rome.

Geremew Taye, Ayalew Adella and Getachew Alemu (2015). Response of Potato (Solanium tubersum L) to Potassium Fertilizer on Acid Soils of Welmera and Gumer wereda, in the Highlands of Ethiopia, Journal of Biology Agriculture and Health Care. Vol 5 No 17 (2015) pp 156-160.

Gete, Z., G. Agegnehu, D. Abera, and S. Rashid. (2010). Fertilizer and Soil Fertility Potential in Ethiopia: 
Constraints and Opportunities for Enhancing the System. http://www. ifpri.org/publication/fertilizer-andsoil-fertility-potentialethiopia.

Haile, W., and T. Mamo. (2013). The Effect of Potassium on the Yields of Potato and Wheat grown on the Acidic Soils of Chencha and Hagere Selam in Southern Ethiopia. International Potash Institute e-ifc 35:3-8.

Havlin, J.L., Tisdale, S.L., Beaton, J.D., and Nelson, W.L (2005). Soil Fertility and Fertilizers. An

Introduction to Nutrient Management, $7^{\text {th }}$ edition, Prentice Hall, New Jersey.

Heuzé, V., H.G. Thiollet Tran, D. Bastianelli, and F. Lebas. (2016). Tef (Eragrostis tef) Grain. Feedipedia, a program by INRA, CIRAD, AFZ and FAO. http://www.feedipedia.org/node/439.

John I. H., E. Mayorga, E. Tsamakis, M. E. McClain, A. Aufdenkampe, P. Quay, and J. E. Richey. (2000). Organic matter in Bolivian tributaries of the Amazon River: A comparison to the lower mainstream, Limnol. Oceanogr., 45(7), 1449-1466, American Society of Limnology and Oceanography, Inc., Washington.

Kamprath, E.J. (1984). Crop response to lime on soils in the tropics p 341- 348. In: Adams F. (ed). Soil acidity and liming.ASA, Madison, Wisconsin.

Ligeyo DO, Gudu SO. Further laboratory screening of More Kenya Maize Inbred lines for Tolerance to Aluminum In: Third year Progress Report, (March 2004 to 28 February 2005). Mcknight Foundation USA Project, EMBBRAPA, Purdue and Cornell University (USA) and Moi University (Kenya) Phase1, 20032005.

Murphy, H. F. (1968). A report on fertility status and other data on some soils of Ethiopia. Experimental Station Bulletin No. 44. Hailesilassie College of Agriculture. Oklahoma State University, 551P.

NFIU (1992). Results of Comparative Fertilizer Trial Conducted on Major Cereal Crops. ADD/NFIU joint working papers No 41 Addis Aabab.Ethiopia. 74p

Niguse Abebe,Fasil Kebede and Eyasu Abereha (2016). Effect of Potassium on Tuber Yield and Yield Component of Potato (SolaniumTubersum ) on Loamy Soils of Atsbi-Wenberta, Tigray, Ethiopia.Vol.6, No.3Journal of Biology, Agriculture and Healthcare www.iiste.org ISSN 2224-3208 (Paper) ISSN 2225093X (Online).

Okalebo, J.R., K.W.Gathua andP.L.Woomer (2002). Laboratory methods of soil and plant analysis: a working manual. $2^{\text {nd }}$ ed. Nairobi: Sacred African Publishers.

Ranist, V.E, M. Verloo, A.Demeyerand J.M. Pauwels (1999). Manual for soil chemistry and fertility laboratory. pp. 50-100.

Redai Weldegebriel, Tesfay Araya and Yemane G.Egziabher (2018). Effect of NPK and Blended Fertilizer Application on Nutrient Uptake and Use Efficiency of Selected Sorghum (Sorghum bicolor (L.) Moench) Varieties Under Rain-fed Condition in Sheraro District, Northern Ethiopia.Momona Ethiopian Journal of Science (MEJS), V10(1):140-156,2018 CCNCS,Mekelle University, ISSN:2220-184X.

SAS/STAT User's Guide:Version 9.1 $1^{\text {th }}$ edn. SAS Institute Inc., Cary, North Carolina.

Seyfu (1997). Tef. Eragrostis tef (Zucc.)Trotter. Promoting the Conservation and Use of Underutilized and Neglected Crops.12, p. 35. Institute of Plant Genetic and Crop Plant Research, Gaterstleben/International Plant Genetic Resources Institute, Rome. http://www. Underutilized -species. Org/documents/PUBLICATIONS/tef.pdf (January, 2011).

Shumoy, H., and K. Raes. (2017). Tef: The Rising Ancient Cereal: What do we know about its Nutritional and Health Benefits? Plant Foods for Human Nutrition 72(4):335-344.

Steel RG, Torrie JH (1986). Principles and procedures of statistics: a biometrical approach. McGraw-Hill.

Tarekegne Berhe (2010), Breeding and genetic resources of Teff (Eragrostis tef) in Ethiopia. Institute of agricultural Research, Addis Ababa, Ethiopia.

Van Reeuwijk, L.P. (2002). Procedures for soil analysis. Technical paper 9. International Soil Reference and Information Centre (ISRIC), The Netherlands.

Wassie Haile and Shiferaw Boke (2011). Response of Irish Potato (Solanum tuberosum) to the Application of Potassium at Acidic Soils of Chencha, Southern Ethiopia. International Journal of Agricultural Biology 13: 595-598.

Zhu F.(2018). Chemical composition and food uses of teff (Eragrostis tef). Food Chem 2018; 239:402-15. 